\title{
Article \\ Open Innovation through Customer Satisfaction: A Logit Model to Explain Customer Recommendations in the Hotel Sector
}

\author{
Mónica Méndez Díaz ${ }^{1, *}$ and Clara Martín Duque ${ }^{2}$ \\ 1 Faculty of Law and Social Sciences, Rey Juan Carlos University, Paseo de los Artilleros s/n, \\ 28032 Madrid, Spain \\ 2 Faculty of Commerce and Tourism, Complutense University of Madrid, Av. de Filipinas, 3, \\ 28003 Madrid, Spain; cmartinduque@ucm.es \\ * Correspondence: monica.mendez.diaz@urjc.es; Tel.: +34-91-488-9024
}

Citation: Díaz, M.M.; Duque, C.M. Open Innovation through Customer Satisfaction: A Logit Model to Explain Customer Recommendations in the Hotel Sector. J. Open Innov. Technol. Mark. Complex. 2021, 7, 180. https://doi.org/10.3390/joitmc7030180

Academic Editors: Seung-Hee Lee and JinHyo Joseph Yun

Received: 9 May 2021

Accepted: 27 July 2021

Published: 1 August 2021

Publisher's Note: MDPI stays neutral with regard to jurisdictional claims in published maps and institutional affiliations.

Copyright: (c) 2021 by the authors. Licensee MDPI, Basel, Switzerland. This article is an open access article distributed under the terms and conditions of the Creative Commons Attribution (CC BY) license (https:// creativecommons.org/licenses/by/ $4.0 /)$.

\begin{abstract}
Open innovation allows the hotel industry to create platforms and channels for collaboration with its customers, which results in a better understanding of their tastes and demands. In the current environment, which is full of uncertainty, many companies have seen their profits decrease, and even the permanence of their businesses endangered due to the COVID-19 pandemic. In such an environment, it is even more necessary to take into account the customer's opinion about the service received, since once the customer makes use of the hotel's services, he/she will recommend the hotel to third parties if he/she is satisfied with it. Through customer satisfaction and subsequent recommendations, the hotel thus obtains new clients and retains old ones. This feedback from the client allows for understanding their priorities in order to jointly design a tailor-made service. It is for this reason that this research has been carried out to analyze the service attributes evaluated by customers. In order to achieve the proposed objectives, a survey instrument was used, as well as a longitudinal study procedure applying logistic regression over a period of one year. The descriptive results and the logistic regression show the level of customer satisfaction with the service and the importance given to each of the selected attributes. In this way, the research shows in which areas innovation strategies should be sought. Although the research offers a model composed of five attributes to measure satisfaction through recommendation with a probability of more than fifty percent, it is necessary to take into account the limitations of the current environment due to COVID-19 or the possibility of extending the multidimensionality of the model. It is necessary to continue to work through open innovation platforms to keep contact with the customer and to update the examined attributes in order to obtain customer satisfaction and feedback.
\end{abstract}

Keywords: open innovation in tourism; satisfaction; recommendation; hotel

\section{Introduction}

In recent years, the hotel sector has seen increasing activity in a highly competitive environment [1-3]. However, the COVID-19 pandemic has almost completely halted tourism. Many hotels have closed either permanently or temporarily [4]. When tourist activity returns to pre-pandemic levels, the hotel sector will have to regain customers' trust and reinforce their brand [4].

In this sense, innovation is an essential tool for differentiation [5-9]. There are start-ups and SMEs with a leadership culture based on open innovation dynamics [10]. It is of utmost importance to adopt this culture for the management of both new and long-established hotels. This adoption will increase their competitive level and the likelihood of remaining open after the crisis caused by the pandemic.

In order to innovate, however, it is essential to have information about the customer's current needs. Of all the customer information we can collect, recommendation systems 
have become essential in recent years to retain clients and attract new ones to a hotel [11]. The importance of referral systems for hotels lies in the fact that customers are not only the ones who ultimately decide to stay at a hotel, but also the ones who, through word of mouth, bring new customers to a hotel. In short, the customer is a key source for innovation in the hotel sector [12].

This concept of innovation for service improvement and differentiation is directly related to the concept of open innovation [6]. This space for collaborative customer innovation with the hotel sector is a source of competitive advantage, strengthening customer relationships and loyalty [12].

Collaborative spaces or platforms (social networks, surveys, etc.) are the means through which customers can express their dissatisfaction with the service received. Customers express their satisfaction by recommending the service to third parties [13], and open innovation becomes a key tool for the analysis and study of this recommendation.

In recent research, recommendation variables have been studied from two points of view. On the one hand, there are many studies whose main focus was positive opinions leading to recommendations $[14,15]$. On the other hand, other studies have analyzed how a set of attributes can influence the customers' opinions which lead to recommendations [16-18].

In this study, the authors have analyzed recommendations in relation to a number of customer satisfaction attributes in hotels around the world as an open innovation channel for hotels. Satisfaction and recommendation, as two related constructs, have been analyzed according to the previous scientific literature. In this sense, the research hypothesis seeks to verify whether the recommendation variable can be explained by positive and significant relationships with customer service, cleanliness, facilities, and value for money. This hypothesis has been tested for all quarters.

Thus, the aim of this study is to analyze the responses given by a number of hotel service customers on the perceived satisfaction of a series of attributes and to verify their relationship with the recommendation of the service to third parties. The weights of the different attributes are also analyzed in order to assess which are the most important in the evaluation of customer satisfaction and subsequent recommendation.

The business ecosystem, through platforms such as the one used in this study, obtains numerous responses from customers about the service. In this way, the customer becomes a source of open innovation since, through their collaboration, they transfer their requirements to the business network and allow the latter to create services in line with the customer's expectations. This research processes and analyzes the relationships of these consumer responses.

\section{Literature Review}

\subsection{Open Innovation in the Tourism Sector through Customers and Their Opinions}

Business innovation must be flexible and, as Chesbrough [19] points out, companies must be open to the opinions of different stakeholders in order to improve and differentiate their services from those of their competitors [6]. Consequently, the company should break down the barriers that separate it from its environment and open up to the different actors that interact with it in order to gain new knowledge [20].

Despite the relevance of this strategy for the improvement of products and services, most of the research conducted on this topic has focused on the development of products in the manufacturing industry [21]. There are, therefore, few studies that deal with this topic in tourism [12]. The special characteristics of the tourism product (heterogeneity, intangibility, expiration, aggregability) make further research on this specific sector necessary [21].

In the service sector, customers are an external part of the business relationship. Their insights provide unique and valuable information about the hotel service. Their ideas and opinions contribute directly to the creation of competitive strategies. By using customers' knowledge and experiences, hotel establishments can receive innovative ideas [12,22]. 
These strategies can also help reduce the risk associated with new product launches and increase the company's creativity levels $[23,24]$. Other authors associate this concept with customer satisfaction and indicate the relevance of innovative systems for increasing customer satisfaction [25].

\subsection{Business Model for the Creation of Innovative Value through Platforms}

The business model is key to the success of innovation, and the company has to identify customer problems and create an innovative value proposition that responds to those problems [26]. The business model has to create innovative processes capable of realizing the value proposition. This business model must be based on openness and collaboration between all parties involved in the business ecosystem [27]. Therefore, there must be continuous communication with suppliers and customers. This communication takes place through networking platforms of suppliers, complementary companies, distributors, promoters, customers, etc. Examples of these digital platforms are those offered by companies such as STR, specialists in benchmarking to improve hotel performance and profitability, or hotel quality for client-company communication.

Through these platforms, the different agents involved can share and evaluate supply and demand in order to have more information and be able to make better business decisions.

There are platforms where tourists can share their experiences and thus become part of the co-creation of activities during the development of new innovations [28], such as WandoExperiences, a digital platform for selling destination experiences. Other platforms allow innovative projects to be shared between administrations. An example of this concept is the smart city.

The regional development impact of these digital platforms is very important. Local businesses in developing countries can benefit from the possibility of using the digital services offered by global platforms. This, together with local knowledge, can be an advantage for locally rooted digital platforms, allowing them to offer services adapted to local demand [29].

\subsection{Customer Satisfaction: Measurement Models}

Understanding the concept of satisfaction is important to guarantee success for any company in the service sector $[30,31]$. Although there are many definitions of satisfaction, there is no defined theoretical framework. However, there is one issue on which all studies agree, and that is the importance of the customer as the subject that perceives this satisfaction [1,25,32-34]. This perception will be conditioned by cognitive and emotional variables [35-37], and these variables will be represented by a series of attributes [38,39]. The customer reflects his or her satisfaction with the service received through the perceived quality of these tangible and intangible elements that form part of the hotel service. Within the models for measuring customer satisfaction, we can find studies focused on cognitive or tangible factors, studies that focus on intangible or emotional factors, and multidimensional studies [40]. These dimensions have been measured through different attributes [34,41,42]. One of the most comprehensive approaches is the Northern European approach: a threedimensional approach that is made up of attributes aimed at measuring technical quality, functional quality, and quality of the result. Technical quality refers to the quality of the physical elements. In the research, the representative attribute for measuring technical quality is the state of the facilities and general cleanliness. Functional quality is the quality of interactions represented by the customer service attribute. Regarding quality of the result, this refers to the final service where the benefits obtained by the clients are measured through the price-quality ratio attribute. Most studies tend to focus more on functional quality than technical, but it is advisable to include both perspectives [43].

\subsection{The Impact of Customer Satisfaction on the Service Recommendation}

Customer loyalty, identified through the recommendation of the product or service, as well as its relationship to satisfaction, has been widely discussed in the specialized 
literature $[37,44-47]$. In the hotel sector, this recommendation is a key factor, fundamentally due to both the difficulty of having the same client evaluating the service before making use of it, as well as its seasonal and perishable nature and the high risk perceived by the client [48].

Many studies explain that the recommendation occurs when the client perceives a service as optimal and experiences a positive emotional response [14,37]. Thus, it should be noted that recommendation is one of the elements that will define a loyal customer [49] and possibly lead to the repurchase of the product or service [17,41]. For a customer to be satisfied, the product must be adapted to his or her needs. In this process, open innovation techniques can help to increase the suitability of the product and therefore customer satisfaction. In this way, we can affirm that open innovation has a positive effect on customer recommendation and customer loyalty [50].

Nonetheless, satisfaction alone is not a guarantee that the customer will recommend the product or service. For this reason, it is important to evaluate what base satisfaction level is needed for a client to recommend it, since there are few studies on this. Reichheld [51] stands out among these studies and establishes that only clients who rate the service between 9 and 10, on a scale of 10, are willing to recommend it. However, this hypothesis is not supported by other authors who indicate that this relationship is not linear [52,53].

The lack of consensus about the relationships between the necessary levels of satisfaction to recommendation leads us to consider the following study. More specifically, a model is proposed consisting of tangible attributes (state of the facilities and cleanliness), intangibles (customer service), and attributes aimed at measuring the result of the service (price-quality). Finally, the recommendation attribute has been included as a way to measure global service satisfaction [41] and customer loyalty [54]. The variables chosen have been used in different research studies (Table 1).

Table 1. Review of the use of service satisfaction assessment attributes.

\begin{tabular}{cl}
\hline \multicolumn{1}{c}{ Attribute } & \multicolumn{1}{c}{ Author (Year) } \\
\hline Customer service & $\begin{array}{l}\text { Tejada Yánez, 2020 [55]; De la Cruz Vargas, (2017) [56]; Herazo } \\
\text { and Huamancayo (2018) [57]; Nunkoo, Teeroovengadum, } \\
\text { Ringle, and Sunnassee (2019) [58]; Chumpitaz (2020) [59] }\end{array}$ \\
\hline Price & $\begin{array}{l}\text { Han and Hyun (2015) [60]; Lima et al. (2017) [61]; Izquierdo, } \\
\text { Remigio, Díaz, and Martínez (2020) [62]; Chumpitaz (2020) [59] }\end{array}$ \\
\hline \multirow{3}{*}{ Cleanliness } & $\begin{array}{l}\text { Malik, Akhtar, Raziq, and Agmad (2018) [59]; Nunko et al. } \\
\text { (2019) [58]; Chumpitaz (2020) [59]; Izquierdo, Remigio, Díaz, } \\
\text { and Martínez (2020) [62] }\end{array}$ \\
\hline \multirow{2}{*}{ Facilities } & $\begin{array}{l}\text { Tefera and Govender (2016) [63]; De la Cruz Vargas (2017) [56]; } \\
\text { Herazo and Huamancayo (2018) [57]; Tejada Yánez (2020) [55] }\end{array}$ \\
\hline \multirow{2}{*}{ Recommendation } & $\begin{array}{l}\text { Emir and Kozac (2011) [54]; Raza et al. (2012) [47]; } \\
\text { Aguilar-Rojas, Fandos, and Flavián-Blanco (2015) [16]; Han and } \\
\text { Hyun (2015) [60]; Le, Nguyen, and Pervan (2020) [64] }\end{array}$ \\
\hline
\end{tabular}

According to the previous background, the main goal of this study is to analyze the relationships between a number of attributes (customer services, general cleanliness, facilities, and quality-price ratio) and the recommendation factor taken from the opinions of a large sample of hotel customers after their stay [41,54]. The methodology, statistical analysis, and results are presented in the following sections.

\section{Materials and Methods}

\subsection{Participants and Procedure}

The data used were derived from the opinions of 165,739 customers during one year (2017) and divided by quarter. Table 2 describes the distribution according to category (number of stars). Four stars was the category with the greatest representation in all 
quarters. Regarding typology, in all quarters, urban hotels have greater weight than resorts. The surveys were conducted in hotels around the world, although the highest percentage of responses was obtained from guests staying in hotels in Mexico (32.22\%), Spain (23.94\%), and Brazil (24.3\%).

Table 2. Number of questionnaires and percentages by category, typology, and country.

\begin{tabular}{cccccc}
\hline \multicolumn{2}{c}{ Variable/Quarter } & First (\%) & Second (\%) & Third (\%) & Fourth (\%) \\
\hline \multirow{3}{*}{ Category } & 5-star & 20.9 & 19.6 & 20.5 & 19.7 \\
\cline { 2 - 6 } & 4 -star & 52.3 & 53.9 & 55.9 & 55.4 \\
\cline { 2 - 6 } & 3 -star & 24.8 & 24.6 & 22.2 & 23.4 \\
\cline { 2 - 6 } Typology & $\leq 2$-star & 2.0 & 1.9 & 1.5 & 1.5 \\
& Urban & 69.5 & 70.1 & 67.4 & 69.8 \\
& Resort & 6.8 & 5.4 & 7.4 & 5.3 \\
\multirow{2}{*}{ Country } & Mexico & 30.1 & 33.5 & 31.2 & 32.2 \\
& Spain & 26.0 & 25.2 & 23.0 & 23.3 \\
\hline \multirow{2}{*}{ Number of questionnaires } & 33.239 & 32.871 & 34.068 & 32.091 \\
\hline
\end{tabular}

A correlational study was conducted throughout four quarters. The survey was based on an open questionnaire with a non-probability convenience sampling. It was made available to hotel clients at the end of their stay, either as a physical copy or electronically through email. Due to the size of the sample, missing data were removed in all variables. The fieldwork and ethics considerations were managed by the company Hotel Quality ( www.hotel-quality.com (accessed on 17 December 2018)) and data were collected in a big database. This company conducted the customer surveys at the end of each quarter, so they in turn provided us with the information on a quarterly basis. In this way, the data were analyzed as they were provided to us. We used the statistical software R in order to analyze the data [65]. The clients filled out the questionnaire voluntarily, no ethical approvals were needed, and there were no rewards for participation in the study.

\subsection{Instrument}

The questionnaire used in this study was structured in two sections. The first part included non-metric variables such as typology (urban or resort), number of hotel stars, and country. In the second one, the customers had to answer to questions about four general attributes: customer services, general cleanliness, facilities, and quality-price ratio. A six-point Likert scale was used to measure customer's opinions, where $1=$ very poor, 2 = poor, 3 = fair, $4=$ good, $5=$ very good, and $6=$ excellent. Moreover, the participants had to say if they would recommend $(Y=1)$ or not recommend $(Y=0)$ the hotel to future clients. The dependent and independent variables were chosen by the data provider (Hotel Quality).

\subsection{Analysis}

A binary logistic regresion, called "logit", has been applied using the software R. The specific function general lineal model "glm" was employed, where the dependent variables are defined as a binomial parameter (family = binomial). A recommendation is denoted as $\mathrm{P}(\mathrm{Y}=1)$ and no recommendation as $1-\mathrm{P}(\mathrm{Y}=1)$. This statistical procedure is developed in the analysis for which the dependent variable is dichotomous. Thus, $X_{1}, X_{2},[\ldots], X_{n}$ ( $n$ is the number of independent variables) are influential variables for finding $Y$, and the logistic regression formula is used to learn the probability ratio for recommendation and no recommendation. The logarithm is $\operatorname{Logit} P=\alpha+\beta 1 \mathrm{X} 1+\beta 2 \mathrm{X} 1+\ldots+\beta \mathrm{m} \mathrm{Xm}$, where $\mathrm{m}$ is the number of independent variables $\mathrm{X} 1, \mathrm{X} 2, \mathrm{X} 3$, and $\mathrm{X} 4$, which in this study are: customer service, facilities, cleanliness, and price-quality ratio [66]. 


\section{Results}

\subsection{Descriptive}

Table 3 includes descriptive results: mean, standard deviation, skewness, and kurtosis, for each attribute and quarter. In all cases, the means were over five points (ranging 1-6) and the standard deviation was from $0.89-1.13$. Moreover, the dichotomous recommendation variable showed, for each quarter, percentages of: $95 \%(Y=1)$ and $5 \%(Y=0)$ for the first quarter; $94.5 \%(\mathrm{Y}=1)$ and $5.5 \%(\mathrm{Y}=0)$ for the second quarter; $94.6 \%(\mathrm{Y}=1)$ and $5.4 \%$ $(\mathrm{Y}=0)$ for the third quarter; and finally, $95 \%(\mathrm{Y}=1)$ and $5 \%(\mathrm{Y}=0)$ for the fourth quarter.

Table 3. Descriptive results of the attributes for each quarter.

\begin{tabular}{cccccc}
\hline Attributes & Quarter & M & SD & Skewness & Kurtosis \\
\hline \multirow{3}{*}{ Customer } & T 1 & 5.412 & 0.8919 & -2.222 & 7.012 \\
service & T 2 & 5.413 & 0.9048 & -2.356 & 7.813 \\
& T 3 & 5.414 & 0.9334 & -2.448 & 8.204 \\
& T 4 & 5.410 & 0.9190 & -2.452 & 8.485 \\
\hline \multirow{2}{*}{ Facilities } & T 1 & 5.375 & 0.8964 & -2.100 & 6.669 \\
& T 2 & 5.409 & 0.8937 & -2.256 & 7.467 \\
& T 3 & 5.390 & 0.9242 & -2.282 & 7.428 \\
& T 4 & 5.380 & 0.9250 & -2.212 & 6.997 \\
\hline \multirow{3}{*}{ Cleanliness } & T 1 & 5.165 & 1.022 & -1.766 & 4.648 \\
& T 2 & 5.203 & 1.009 & -1.875 & 5.248 \\
& T 3 & 5.184 & 1.034 & -1.830 & 4.749 \\
Price-quality & T 4 & 5.210 & 0.9990 & -1.842 & 5.034 \\
ratio & T 1 & 5.000 & 1.133 & -1.678 & 4.059 \\
& T 2 & 5.025 & 1.088 & -1.608 & 3.846 \\
& T 3 & 5.022 & 1.101 & -1.595 & 3.658 \\
& T 4 & 5.050 & 1.098 & -1.705 & 4.244 \\
\hline
\end{tabular}

\subsection{Results of the Logit Regression for the Four Quarters}

Table 4 includes the logistic regression findings for each quarter. For the first quarter, customer services ( $\mathrm{W}=117.196, p<0.01)$, facilities $(\mathrm{W}=78.578, p<0.01)$, and price-quality ratio $(W=245.785, p<0.01)$ were positive and significant. However, cleanliness was not significant $(\mathrm{W}=3.208, p>0.05)$. For the second quarter, all attributes were significant, for instance, customer services ( $W=96.086, p<0.01)$, facilities $(W=51.687, p<0.01)$, cleanliness $(\mathrm{W}=16.049, p<0.01)$, and price-quality ratio $(\mathrm{W}=280.598, p<0.01)$. For the third quarter, cleanliness was not significant for the regression model $(\mathrm{W}=0.852, p>0.05)$. Customer services $(\mathrm{W}=93.628, p<0.01)$, facilities $(\mathrm{W}=92.891, p<0.01)$, and price-quality ratio $(\mathrm{W}=276.039, p<0.01)$ had a positive and significant relationship with the dichotomous recommendation variable. Finally, for the fourth quarter, all variables had a positive and significant relationship with the dependent variables of the model: customer services $(\mathrm{W}=73.447, p<0.01)$, cleanliness $(\mathrm{W}=5.24, p=0.022)$, facilities $(\mathrm{W}=46.206, p<0.01)$, and price-quality ratio $(\mathrm{W}=243.443, p<0.01)$. These results show that independent and significant variables of the model have a positive impact on the probability to recommend the hotel. In all quarters, the price-quality ratio variable is, according to the statistical findings, more important than the rest of the attributes. For all quarters, the Nagelkerke $\mathrm{R}^{2}$ index was 0.51-0.58. 
Table 4. Results of the logit regression for each quarter.

\begin{tabular}{|c|c|c|c|c|}
\hline & Variables & B & Wald & Sig. \\
\hline \multirow{5}{*}{ First quarter } & Constant $(\alpha)$ & -8.105 & 427.194 & 0.000 \\
\hline & $\begin{array}{c}\text { Customer } \\
\text { service }\end{array}$ & 0.700 & 117.196 & $0.000 * *$ \\
\hline & Facilities & 0.672 & 78.578 & $0.000 * *$ \\
\hline & Cleanliness & 0.135 & 3.208 & 0.073 \\
\hline & $\begin{array}{l}\text { Price-quality } \\
\text { ratio }\end{array}$ & 1.049 & 245.785 & $0.000^{* *}$ \\
\hline \multirow{5}{*}{ Second quarter } & $\alpha$ Constant $(\alpha)$ & -7.566 & 467.709 & 0.000 \\
\hline & $\begin{array}{c}\text { Customer } \\
\text { service }\end{array}$ & 0.582 & 96.086 & $0.000^{* *}$ \\
\hline & Facilities & 0.509 & 51.687 & $0.000^{* *}$ \\
\hline & Cleanliness & 0.292 & 16.049 & $0.000^{* *}$ \\
\hline & $\begin{array}{l}\text { Price-quality } \\
\text { ratio }\end{array}$ & 0.980 & 280.598 & $0.000 * *$ \\
\hline \multirow{5}{*}{ Third quarter } & Constant $(\alpha)$ & -7.787 & 430.678 & 0.000 \\
\hline & $\begin{array}{c}\text { Customer } \\
\text { service }\end{array}$ & 0.645 & 93.628 & $0.000 * *$ \\
\hline & Facilities & 0.719 & 92.891 & $0.000^{* *}$ \\
\hline & Cleanliness & 0.069 & 0.852 & 0.356 \\
\hline & $\begin{array}{l}\text { Price-quality } \\
\text { ratio }\end{array}$ & 1.052 & 276.039 & $0.000 * *$ \\
\hline \multirow{5}{*}{ Fourth quarter } & Constant $(\alpha)$ & -7.387 & 375.378 & 0.000 \\
\hline & $\begin{array}{l}\text { Customer } \\
\text { service }\end{array}$ & 0.602 & 73.447 & $0.000 * *$ \\
\hline & Facilities & 0.532 & 46.206 & $0.000^{* *}$ \\
\hline & Cleanliness & 0.174 & 5.24 & 0.022 * \\
\hline & $\begin{array}{l}\text { Price-quality } \\
\text { ratio }\end{array}$ & 1.059 & 243.443 & $0.000^{* *}$ \\
\hline
\end{tabular}

Nagelkerke $\mathrm{R}^{2}$ for the first quarter $=0.550$; Nagelkerke $\mathrm{R}^{2}$ for the second quarter $=0.519$; Nagelkerke $\mathrm{R}^{2}$ for the third quarter $=0.584 ;$ Nagelkerke $R^{2}$ for the fourth quarter $=0.534 ;{ }^{* *} p<0.01 ; * p<0.05$.

\section{Discussion}

According to the results, in all quarters, some of the attributes showed a significant relationship to the recommendation intention of the clients, thus allowing us to partially accept the hypothesis put forward in the research. These results are in agreement with those found by numerous authors who have investigated this relationship [32,55-57,67].

Each attribute has a different weight and this conclusion is shared by different authors [68-70].

The results of the research reflect how the most important attribute is price-quality ratio in order to explain if the clients would recommend the hotel to another tourist. This conclusion has been reached by several authors, such as Ali et al. [43], Prasetyo et al. [30], and Zagarra et al. [71]. However, cleanliness was not significant in some of the quarters. Due to the pandemic context, these results could be different because new cleanliness measures have been imposed, and this could change the intention of the customer to recommend the hotel in the future. In fact, several authors have identified cleanliness as the clients' most important factor for recommending a service [72,73].

Moreover, customer services and facilities were significant in all quarters as well. These data are consistent with studies by Kim-Soon et al. and Lai and Nguyen [74,75].

Most customers in this sample justify their intention to recommend the hotel according to quality-price ratio, customer services, and facilities. Additionally, some quarters showed cleanliness as an important variable to include in the recommendation model [51].

These results have direct implications for the business ecosystem of hotel establishments. On the one hand, this research confirms the direct and positive relationship between customer satisfaction and recommendation. In this way, it confirms how a customer sat- 
isfied with the service received recommends the service to third parties. Therefore, it is essential for managers to know the attributes that lead the consumer to leave the hotel satisfied. Observing the results, the attribute with the greatest weight when it comes to recommending the service is quality-price, so that when it comes to innovating in the search for a business strategy, this attribute must come first, so that hotel management focuses on providing a service whose quality, with respect to the price paid by the consumer, is perceived as high. The results show how companies should look for innovative strategies with respect to the price-quality ratio, since innovating in this area would make a difference in one of the most important aspects for the hotel customer. To this end, it is necessary to work in an environment of collaboration with the rest of the hotel companies, since in order to improve the perception of this attribute it is not only necessary to study the companies in the ecosystem from a competitive perspective (benchmarking), but also from a collaborative perspective.

While price-quality ratio is the attribute with the greatest weight, customer service has positioned itself as the second most important attribute for customer satisfaction. This implies the need to create innovative policies that pursue employee satisfaction so that, in turn, through them, the customer perceives a high-quality service with respect to the treatment received.

On the other hand, this study has implications for the use of platforms as a business model. Hotel service rating platforms, such as the one used in this study, are what allow stakeholders to know the tastes and needs of the customer. This makes it necessary for the hotel business ecosystem to commit to the permanent and continuous use of this type of tool, as it is through them that they are able to connect their businesses with users and other companies. The hotel should encourage its customers to comment on their experience. In this way, the more companies that join a project in which their users can express themselves through a service rating communication platform, the more data they will obtain, and from their analysis they will be able to co-develop innovative services to satisfy the customer. The digital platform providing the data has enabled communication within the hotel business ecosystem. Customers, through their opinions and assessment of attributes when recommending the service, become co-creators of new innovation projects, as indicated by Hernández and Robles [27].

In spite of the results, this study possesses some limitations. First of all, although there is a large sample, the clients were selected through a non-probability sampling method, which could affect the final results. Additionally, the number of clients who would recommend the hotel was larger than the number of clients who would not recommend the hotel. Furthermore, the questionnaire was a self-reporting tool, and it should be taken into account that the participants may have given biased answers. Additionally, logit regression has been applied for all quarters; according to the findings, the statistical procedure could have been applied for all data together, in order to check if the findings were the same or different. The data provided were quarterly, so it was decided to survey the data accordingly. Based on the results obtained, it is decided to carry out an annual analysis with a single logit in the future.

On the other hand, this study was carried out with the attributes chosen by the supplier company. Although these attributes have been widely used throughout the latest research in this field, we believe that there are few attributes, so for future research, measurement models composed of more than four attributes should be used. This fact will be checked in the future with this and other samples and also the effect of imbalance on the data (recommend vs. do not recommend).

Finally, the pandemic context could influence the recommendation opinion of the customers, especially in regard to the importance of the cleanliness attribute, for instance. For these reasons, a possible study in the future should include more attributes in order to know what the hotel recommendation variables are and how the cleanliness measures could change the importance of the model's quality-price ratio. Furthermore, these studies 
in the current pandemic context should include balanced samples with respect to the recommendation variable [66].

\section{Conclusions}

The logit regression model has shown, on the one hand, the importance of a multidimensional model for the evaluation of satisfaction and, on the other hand, the different weights of each of the attributes. Although the results have shown that the attribute with the highest weight is value for money, it is important to take into account the current pandemic situation, since some attributes such as cleanliness could have acquired greater relevance. Therefore, future research should study consumer evaluations during this crisis and the importance given to the different attributes examined. Future results could show the growing importance of this attribute and the need to develop innovation mechanisms with respect to this attribute.

Companies are currently facing new forms of communication through platforms that allow them to reach their users directly, get to know them in depth, and build loyalty, which means new business opportunities, as well as the generation of innovative ideas that help them to continue to grow and achieve business success. It is of utmost importance that hotels use open innovation platforms to benefit from this customer-company collaboration, as they can identify the degree of customer satisfaction with the service, the elements they examine in the process, and their willingness to recommend. Thus, customer participation in open innovation processes is essential in the industry. Customers are a source of ideas and are the main agents of co-development of the service. This research shows how, in order to customize the hotel service, companies must include the management of an open business model in which the customer is the one who indicates which attributes should be emphasized and how to innovate in these services.

The channel for collecting customer information has made it possible to identify those elements where greater innovation efforts are needed, for example, in relation to the price-quality ratio attribute, so that managers can use this knowledge to develop innovative revenue management policies and strategies to attract new customers and retain existing ones.

This research provides hotel managers with a tool to understand the attributes by which they should seek to innovate. In this way, managers can identify those services they need to improve in order for the customer to be fully satisfied and recommend the service to others. The hotel identifies perceived strengths and weaknesses through the customer, allowing the hotel to focus on improving the sub-optimal part of the service, thereby increasing satisfaction and the likelihood of customers recommending the service. Business leadership based on a culture of open innovation dynamics through the customer will increase the effectiveness of the service quality strategy and management processes, resulting in accelerated business recovery from the pandemic and improved business performance.

Author Contributions: Conceptualization, M.M.D.; methodology M.M.D.; software, M.M.D.; validation, M.M.D.; formal analysis, M.M.D.; investigation, M.M.D.; resources, C.M.D. and M.M.D.; writing-original draft preparation, M.M.D.; writing—review and editing, M.M.D.; visualization, M.M.D.; supervision, M.M.D.; project administration, M.M.D. and C.M.D.; funding acquisition, M.M.D. All authors have read and agreed to the published version of the manuscript.

Funding: This work has not been funded.

Institutional Review Board Statement: Not applicable.

Informed Consent Statement: Not applicable.

Acknowledgments: The authors thank Hotel Quality (www.hotel-quality.com (accessed on 17 July 2018)) for facilitating the database.

Conflicts of Interest: The authors declare no conflict of interest. 


\section{References}

1. Abrudan, I.N.; Pop, C.M.; Lazăr, P.S. Using a General Ordered Logit Model to Explain the Influence of Hotel Facilities, General and Sustainability-Related, on Customer Ratings. Sustainability 2020, 12, 9302. [CrossRef]

2. Nunes, S.; Estevão, C.; Nicolau Filipe, M. Determinant factors of competitiveness in the hotel sector: The case of Portugal. Compet. Rev. 2018, 28, 122-135. [CrossRef]

3. Tussyadiah, I.P.; Zach, F.J. Hotels vs. Peer-to-Peer Accommodation Rentals: Text Analytics of Consumer Reviews. SSRN Electron J. 2015. [CrossRef]

4. Rodríguez-Antón, J.M.; Alonso-Almeida, M.D.M. COVID-19 Impacts and Recovery Strategies: The Case of the Hospitality Industry in Spain. Sustainability 2020, 12, 8599. [CrossRef]

5. Stamboulis, Y.; Skayannis, P. Innovation strategies and technology for experience-based tourism. Tour. Manag. 2003, 24, 35-43. [CrossRef]

6. Chesbrough, H.W. Open Innovation: The New Imperative for Creating and Profiting from Technology; First Trade Paper Edición; McGraw-Hill Education Ltd.: New York, NY, USA, 2006.

7. Fagerberg, J.; Godinho, M.M. Innovation and Catching-Up. 2004. Available online: https://smartech.gatech.edu/bitstream/ handle/1853/43208/ManuelGodinho_1.pdf?sequence=1\&isAllowed=y (accessed on 17 December 2020).

8. Weiermair, K. Product Improvement or Innovation: What Is the Key to Success in Tourism? 2004. Available online: https://www. researchgate.net/publication/242488511_Product_improvement_or_innovation_what_is_the_key_to_success_in_tourism (accessed on 17 December 2020).

9. Duarte, V.; Sarkar, S. Separating the wheat from the chaff-A taxonomy of open innovation. Eur. J. Innov. Manag. 2011, 14, 435-459. [CrossRef]

10. Yun, J.J.; Zhao, X.; Jung, K.; Yigitcanlar, T. The culture for open innovation dynamics. Sustainability 2020, 12, 5076. [CrossRef]

11. Ramzan, B.; Bajwa, I.S.; Jamil, N.; Amin, R.U.; Ramzan, S.; Mirza, F.; Sarwar, N. An Intelligent Data Analysis for Recommendation Systems Using Machine Learning. 2019. Available online: https://www.hindawi.com/journals/sp/2019/5941096/ (accessed on 17 December 2020)

12. Iglesias-Sánchez, P.P.; Correia, M.B.; Jambrino-Maldonado, C. The Customer as a Source of Open Innovation in the Tourism Sector. In The Role of Knowledge Transfer in Open Innovation; Almeida, H., Sequeira, B., Eds.; IGI Global: Hershey, PA, USA, 2019; pp. $158-178$.

13. Górska-Warsewicz, H.; Kulykovets, O. Hotel Brand Loyalty-A Systematic Literature Review. Sustainability 2020, $12,4810$. [CrossRef]

14. Akinci, S.; Aksoy, S. The impact of service recovery evaluation on word-of-mouth intention: A moderated mediation model of overall satisfaction, household income and gender. Tour. Manag. Perspect. 2019, 31, 184-194. [CrossRef]

15. Caruana, S.; Schembri, C. The Significance of Electronic Word of Mouth (e-WOM) Content in the Shaping of the Visitor's Perception of Quality and Value. In Tourism and Culture in the Age of Innovation; Katsoni, V., Stratigea, A., Eds.; Springer Proceedings in Business and Economics: Berlin/Heidelberg, Germany, 2016; pp. 535-550.

16. Aguilar-Rojas, O.; Fandos-Herrera, C.; Flavián-Blanco, C. What may lead you to recommend and revisit a hotel after a service failure instead of complaining? Int. J. Contemp. Hosp. Manag. 2015, 27, 214-235. [CrossRef]

17. Hosany, S.; Prayag, G.; Van Der Veen, R.; Huang, S.; Deesilatham, S. Mediating Effects of Place Attachment and Satisfaction on the Relationship between Tourists' Emotions and Intention to Recommend. J. Travel Res. 2016, 56, 1079-1093. [CrossRef]

18. Perez-Aranda, J.; Guerreiro, M.M.; Da Costa Mendes, J. Predictors of positive reviews on hotels: Hoteliers' perception. Online Inf. Rev. 2018, 42, 146-160. [CrossRef]

19. Chesbrough, H.W. Open Services Innovation: Rethinking Your Business to Grow and Compete in a New Era; Illustrated Edición; John Wiley \& Sons: Hoboken, NJ, USA; Jossey-Bass: San Francisco, CA, USA, 2011.

20. Laursen, K.; Salter, A. Open for innovation: The role of openness in explaining innovation performance among U.K. manufacturing firms. Strateg. Manag. J. 2005, 27, 131-150. [CrossRef]

21. Aas, T.H. Open Service Innovation: The Case of Tourism Firms in Scandinavia. J. Entrep. Manag. Innov. 2016, 12, 53-75. [CrossRef]

22. Prahalad, C.K.; Ramaswamy, V. Co-opting Customer Competence. 2000. Available online: https://hbr.org/2000/01/co-optingcustomer-competence (accessed on 17 December 2020).

23. Aguirre, W.B.P.; Arévalo, M.A.P.; Núñez, L.B.A. Análisis del procesos innovador de las microempresas del área urbana del Cantón Quevedo, Ecuador. ECA Sinergia 2017, 8, 95-108. [CrossRef]

24. Chesbrough, H.W. Bringing Open INNOVATION to Services. 2011. Available online: https://sloanreview.mit.edu/wp-content/ uploads/2010/12/a4daa5e156.pdf (accessed on 17 December 2020).

25. Hermawati, A.; Nurwati, N.; Suhana, S.; Machmuddah, Z.; Ali, S. Satisfaction, HR, and Open Innovation in Tourism Sector. J. Open Innov. 2020, 6, 182. [CrossRef]

26. Mäkinen, S.J.; Kanniainen, J.; Peltola, I. Investigating Adoption of Free Beta Applications in a Platform-Based Business Ecosystem. J. Prod. Innov. Manag. 2014, 31, 451-465. [CrossRef]

27. Majava, J.; Kinnunen, T.; Kess, P.; Leviäkangas, P. Spatial Health and Life Sciences Business Ecosystems: Research Frame. Manag. 2014, 9, 307-322.

28. Hernández, I.J.G.; Robles, F.S. Ecosistemas de negocios a través de plataformas tecnológicas. Ingenio Y Concienc. Boletín Científico De La Esc. Super. Ciudad Sahagún 2018, 5. [CrossRef] 
29. Conferencia de Las Naciones Unidas Sobre Comercio y Desarrollo Plataformas Digitales y Creación de Valor En Los Países En Desarrollo: Repercusiones En Las Políticas Nacionales e Internacionales. 2020. Available online: https://unctad.org/system/ files/official-document/tdb_ede4d2_es.pdf (accessed on 3 July 2021).

30. Jou, R.C.; Day, Y.J. Application of Revised Importance-Performance Analysis to Investigate Critical Service Quality of Hotel Online Booking. Sustainability 2021, 13, 2043. [CrossRef]

31. Chen, C.M.; Lee, H.T.; Chen, S.H.; Huang, T.H. Tourist behavioural intentions in relation to service quality and customer satisfaction. Int. J. Tour. Res. 2011, 13, 416-432. [CrossRef]

32. Parasuraman, A.; Zeithaml, V.A.; Berry, L.L. Reassessment of expectations as a Comparison Standard in Measuring Service Quality: Implications for Further Research. J. Market. 1994, 58. [CrossRef]

33. Carev, D. Guest Satesfaction and Gest Loyalety Study for Hotel Industry. 2008. Available online: https://scholarworks.rit.edu/ theses/508/ (accessed on 17 December 2020).

34. Prasetyo, Y.T.; Tanto, H.; Mariyanto, M.; Hanjaya, C.; Young, M.N.; Persada, S.F.; Redi, A.A.N.P. Factors Affecting Customer Satisfaction and Loyalty in Online Food Delivery Service during the COVID-19 Pandemic: Its Relation with Open Innovation. J. Open Innov. 2021, 7, 76. [CrossRef]

35. Oliver, R. Satisfaction. In A Beavioral Perspective on the Consumer; McGraw-Hill: Singapore, 1997.

36. Bigné, E.; Andreu, L. Modelo Cognitivo-Afectivo de La Satisfacción En SERVICIOS de ocio y Turismo. 2004. Available online: https:/ / dialnet.unirioja.es/servlet/articulo?codigo=1143456 (accessed on 17 December 2020).

37. Sukhu, A.; Choi, H.; Bujisic, M.; Bilgihan, A. Satisfaction and positive emotions: A comparison of the influence of hotel guests' beliefs and attitudes on their satisfaction and emotions. Int. J. Hosp. Manag. 2019, 77, 51-63. [CrossRef]

38. Medina, P.; Salas, J.R.; Sánchez, V.; Álvarez, W.T. Análisis Documental Sobre Calidad y Seguridad Turística En Las Festividades de Tungurahua. 2019. Available online: https://dialnet.unirioja.es/servlet/articulo?codigo=6836430 (accessed on 17 December 2020).

39. Taylan Dortyol, I.; Varinli, I.; Kitapci, O. How do international tourists perceive hotel quality? Int. J. Contemp. Hosp. Manag. 2014, 26, 470-495. [CrossRef]

40. Argudo-Pesántez, B.L.; Narváez-Zurita, C.I.; Vásquez-Erazo, E.J. Percepción de la Satisfacción del Cliente Externo: Centro Clínico Quirúrgico Ambulatorio Hospital del Día Azogues. Cienciamatria 2021, 7, 545-574. [CrossRef]

41. Baniya, R.; Thapa, P. Hotel Attributes Influencing International Tourists' Satisfaction and Loyalty. J. Tour. Hosp. Education 2017, 7, 44-61. [CrossRef]

42. Ban, H.J.; Choi, H.; Choi, E.K.; Lee, S.; Kim, H.S. Investigating Key Attributes in Experience and Satisfaction of Hotel Customer Using Online Review Data. Sustainability 2019, 11, 6570. [CrossRef]

43. Ali, F.; Hussain, K.; Konar, R.; Jeon, H.M. The Effect of Technical and Functional Quality on Guests' Perceived Hotel Service Quality and Satisfaction: A SEM-PLS Analysis. J. Qual. Assur. Hosp. Tour. 2016, 18, 354-378. [CrossRef]

44. Bowen, J.T.; Shiang-Lih, C. The relationship between customer loyalty and customer satisfaction. Int. J. Contemp. Hosp. Manag. 2001, 13, 213-217. [CrossRef]

45. Kandampully, J.; Suhartanto, D. Customer loyalty in the hotel industry: The role of customer satisfaction and image. Int. J. Contemp. Hosp. Manag. 2000, 12, 346-351. [CrossRef]

46. Oh, H. Service quality, customer satisfaction, and customer value: A holistic Perspective. Int. J. Hosp. Manag. 1999, 18, 67-82. [CrossRef]

47. Raza, M.A.; Siddiquei, A.N.; Awan, H.M.; Bukhari, K. Relationship between Service Quality, Perceived Value, Satisfaction and Revisit Intention in Hotel Indry. 2012. Available online: https://journal-archieves26.webs.com/788-805.pdf (accessed on 17 December 2020).

48. Litvin, S.W.; Goldsmith, R.E.; Pan, B. Electronic word-of-mouth in hospitality and tourism management. Tour. Manag. 2008, 29, 458-468. [CrossRef]

49. Múgica, J.; Berné, C. Direct and Indirect Tourism Online Channels. Do They Have a Different Potential for Customer Loyalty? Sustainability 2020, 12, 4761. [CrossRef]

50. Suwannaporn, P.; Speece, M.W. Assessing new product development success factors in the Thai food industry. Br. Food J. 2010, 12, 364-386. [CrossRef]

51. Reichheld, F. The Ultimate Question 2.0 (Revised and Expanded Edition): How Net Promoter Companies Thrive in a Customer-Driven World; Revised and Expanded Edition; Harvard Business Review Press: Boston, MA, USA, 2014.

52. Mittal, V.; Kamakura, W.A. Satisfaction, repurchase intent, and repurchase behavior: Investigating the moderating effect of customer characteristics. J. Mark. Res. 2001, 13, 31-42. [CrossRef]

53. Kumar, P. The impact of performance, cost, and competitive considerations on the relationship between satisfaction and repurchase intention business markets. J. Serv. Res. 2002, 5, 55-68. [CrossRef]

54. Emir, O.; Kozak, M. Perceived Importance of Attributes on Hotel Guests' Repeat Visit Intentions. 2011. Available online: https:/ / hrcak.srce.hr/71005 (accessed on 17 December 2020).

55. Tejada Yáñez, T.M. Experiencia de Marca, Satisfacción y Lealtad de Huéspedes de Hoteles 3 Estrellas de Cadenas Nacionales En Miraflores 2019. 2020. Available online: http://repositorio.usil.edu.pe/bitstream/USIL/9944/1/2020_Tejada\%20Y\%C3\%A1\%C3 \%B1ez.pdf (accessed on 17 December 2020). 
56. De La Cruz Vargas, A.D. Calidad de Servicio, Satisfacción y Lealtad, En Los Estudiantes de La Universidad Peruana Unión, 2016. 2017. Available online: https:/ / repositorio.upeu.edu.pe/bitstream/handle/UPEU/1130/Alexander_Tesis_Doctor_2017.pdf? sequence $=5 \&$ isAllowed $=y$ (accessed on 17 December 2020).

57. Herazo Pachas, G.; Huamancayo Balarezo, J.A. Relación de La Calidad de Servicio, La Satisfacción y Lealtad de Marca de Los Clientes de Latam En Vuelos Nacionales En El 2017. 2018. Available online: http://repositorio.usil.edu.pe/bitstream/USIL/3925 /1/2018_Herazo-Pachas.pdf (accessed on 17 December 2020).

58. Nunkoo, R.; Teeroovengadum, V.; Ringle, C.M.; Sunnassee, V. Service quality and customer satisfaction: The moderating effects of hotel star rating. Int. J. Hosp. Manag. 2019, 91, 102414. [CrossRef]

59. Chumpitaz Prada, Ibrahim Joao La Calidad Del Servicio de Alojamiento y El Nivel de Satisfacción de Los Clientes Del Hotel Camino Real de La Ciudad de Tacna en El Año 2019. 2020. Available online: http:/ / repositorio.upt.edu.pe/bitstream/UPT/1641 /1/Chumpitaz-Prada-Ibrahim.pdf (accessed on 17 December 2020).

60. Han, H.; Hyun, S.S. Customer retention in the medical tourism industry: Impact of quality, satisfaction, trust, and price reasonableness. Tour. Manag. 2015, 46, 20-29. [CrossRef]

61. Lima, S.M.; Viana, F.L.E. Criterios Competitivos En Operaciones de Servicios de Hotelería En El Contexto de Online Travel Reviews. 2017. Available online: https: / / dialnet.unirioja.es/servlet/articulo? codigo=6328656 (accessed on 17 December 2020).

62. Izquierdo, A.; Remigio, G.; Díaz González, Y.; Martínez Martínez, C.C. Calidad Percibida Por Los Clientes de Los Hoteles de La Provincia Los Ríos, Ecuador. 2020. Available online: https:/ / dialnet.unirioja.es/servlet/articulo?codigo=7687046 (accessed on 17 December 2020).

63. Tefera, O.; Govender, K. From Servqual to Hotsperf: Towards the Development and Validation of an Alternate Hotel Service Quality Measurement Instrument. 2016. Available online: https://www.researchgate.net/publication/30861518 6_From_SERVQUAL_to_HOTSPERF_Towards_the_Development_and_Validation_of_an_alternate_Hotel_Service_Quality_ Measurement_Instrument (accessed on 17 December 2020).

64. Nguyen, H.T.T.; Nguyen, N.; Pervan, S.; Le, V.H. Development and validation of a scale measuring hotel website service quality (HWebSQ). Tour. Manag. Perspect. 2020, 35, 100687.

65. R Foundation for Statistical Computing. R Development Core Team R: A Language and Environment for Statistical Computing; $\mathrm{R}$ Foundation for Statistical Computing: Vienna, Austria, 2008; Available online: http://www.R-project.org (accessed on 17 December 2020).

66. Fernández-Muñoz, J.J.; Moguerza, J.M.; Duque, C.M.; Bruna, D.G. A study on the effect of imbalanced data in tourism recommendation models. Int. J. Qual. Serv. Sci. 2019, 11, 346-356. [CrossRef]

67. Silva-Treviño, J.G.; Macías-Hernández, B.A.; Tello-Leal, E.; Delgado-Rivas, J.G. La relación entre la calidad en el servicio, satisfacción del cliente y lealtad del cliente: Un estudio de caso de una empresa comercial en México. Ciencia UAT 2021, 15, 85-101. [CrossRef]

68. Akbaba, A. Measuring service quality in the hotel industry: A study in a business hotel in Turkey. Int. J. Hosp. Manag. 2006, 25, 170-192. [CrossRef]

69. Gržinić, D. Concepts of Service Quality Measurement in Hotel Industry. 2007. Available online: https://www.researchgate.net/ publication/27200641_Concepts_of_service_quality_measurement_in_hotel_industry (accessed on 17 December 2020).

70. Debasish, S.S.; Dey, M.S. Customer Perceptions of Service Quality towards Luxury Hotels in Odisha Using SERVQUAL Model. 2015. Available online: http:/ / www.ijrbsm.org/pdf/v2-i9/1.pdf (accessed on 17 December 2020).

71. Zegarra, M.M.; Mafé, C.R. El valor hedónico como determinante clave de la intención de recompra y de recomendación en el comercio móvil de productos de moda. UCJC Bus. Soc. Rev. 2020, 17, 54-91.

72. Jiménez-Barreto, J.; Loureiro, S.; Braun, E.; Sthapit, E.; Zenker, S. Use numbers not words! Communicating hotels' cleaning programs for COVID-19 from the brand perspective. Int. J. Hosp. Manag. 2021, 94, 102872. [CrossRef]

73. World Health Organization. Operational Considerations for COVID-19 Management in the Accommodation Sector. 2019. Available online: https://apps.who.int/iris/bitstream/handle/10665/331638/WHO-2019-nCoV-Hotels-2020.1-eng.pdf (accessed on 17 December 2020).

74. Kim-Soon, N.; Ahmad, A.R.; Logeswaary, V. SERVQUAL: Can It be Used to Differentiate Guest's Perception of Service Quality of 3 Star from a 4 Star Hotel. 2014. Available online: https:/ / www.researchgate.net/publication/264707509_SERVQUAL_Can_It_ Be_Used_to_Differentiate_Guest $\backslash \mathrm{T} 1 \backslash$ textquoterights_Perception_of_Service_Quality_of_3_Star_from_a_4_Star_Hotel (accessed on 17 December 2020).

75. Lai, C.-S.; Minh, C.N. Factors Affecting Service Quality, Customer Satisfaction and Loyalty of Mobile Phone Service Providers in Vietnam. 2017. Available online: https:/ /joi-online.org/attachments/article/54/FINAL\%20ISSUE\%20VOL\%2010\%20NUM\% 202\%20OCTOBER\%202017\%20-\%20SECTION\%20A.pdf\#page=75 (accessed on 17 December 2020). 